\title{
A diagnosis that will go down in history
}

\section{A well described case in the Christmas tradition is that of Patient $R$, reported to have been afflicted with a very shiny nose. We believe his presentation was consistent with one of the cutaneous forms of sarcoidosis: lupus pernio.}

A well described case in the Christmas tradition is that of Patient $R$, reported to have been afflicted with a very shiny nose. The lesion was described as having a lustrous, glowing appearance and initially exerting a significant burden on quality of life - the patient's peers engaged in name-calling and excluded him from social games. It would seem that the case proved a challenge diagnostically, with the disease managed expectantly. Fortuitously, it availed itself to a particularly coveted job prospect which in time eventuated in acceptance by his peers and, notably, this transpired with glee. The case has remained a diagnostic dilemma through the generations. It has been proposed that the cutaneous lesion might be attributable to variations in nasal microcirculation noted in specific genetic populations. ${ }^{1}$ However, the uniqueness of Patient R's lesion is what has made him a legend and, accordingly, a diagnosis of variations in nasal microcirculation seems unlikely. Rather, a pathological aetiology is more in keeping with his clinical picture. We believe Patient $\mathrm{R}$ was afflicted with one of the cutaneous forms of sarcoidosis: lupus pernio.

The clinical presentation of lupus pernio is that of violaceous papules, nodules or plaques. The lesions have an indurated, shiny, and somewhat bright character to them and are classically located on the nose, but also the cheeks and ears: in those areas most sensitive to the cold, or "pernio", that one might experience one foggy Christmas Eve. In lupus pernio, histological findings are remarkable for the presence of sarcoidal granulomas, with birefringent material observed in up to $50 \%$ of cases (you could even say they glow). ${ }^{2}$

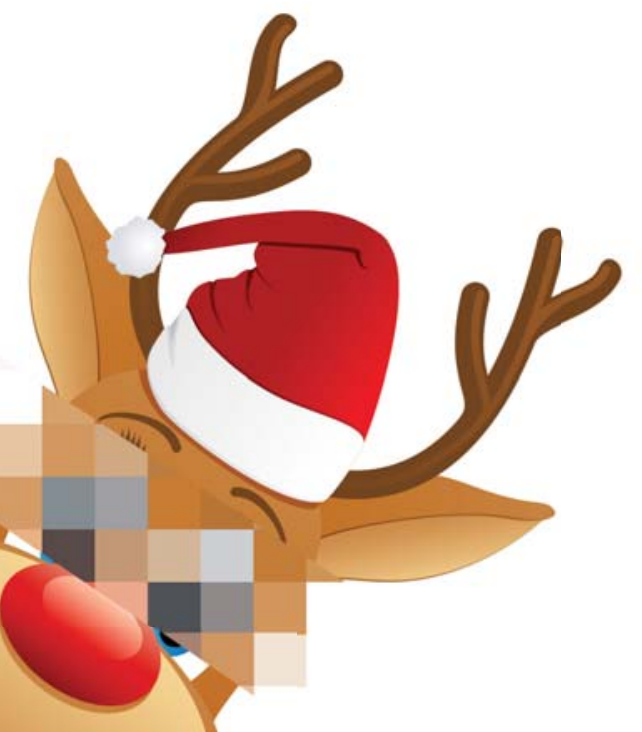

Deshan F Sebaratnam MBBS(Hons), MMed Dermatology Registrar ${ }^{1,2}$

Nicholas Stewart MBBS, BSC Dermatology Registrar,

Supriya S Venugopal MBBS, MMed, FACD Dermatologist $^{2}$

1 Department of Dermatology, Westmead Hospital Sydney, NSW.

2 Skin and Cancer Foundation Australia, Sydney, NSW.

d.sebaratnam@ hotmail.com

doi: 10.5694/mjal4.00786 \section{.}

.

An important clinical consideration in patients with lupus pernio is the association with pulmonary sarcoidosis. It has been reported that $74 \%$ of patients will have intrathoracic disease and $54 \%$ will have upper respiratory tract involvement. ${ }^{3}$ This form of cutaneous sarcoidosis portends a more aggressive clinical course with a higher likelihood of visceral involvement and recalcitrance to therapy. Cutaneous sarcoidosis is known for its protean clinical presentations, including erythema nodosum, macules, papules and plaques, scar sarcoidosis, ichthyosis, Darier-Roussy lesions, alopecia and onychodystrophy. ${ }^{4}$ Physicians should be aware of cutaneous signs of sarcoidosis because they lend themselves to biopsy facilitating diagnosis, many have prognostic significance, and they can impose a significant burden on quality of life. ${ }^{5}$

Based on morphology alone, a wide range of differential diagnoses could account for Patient R's clinical presentation (Box). However, considering the history and examination findings together, lupus pernio represents a unifying diagnosis. This patient's story represents an instructive case and is one that will go down in history.

Competing interests: No relevant disclosures.

1 Ince C, van Kuijen AM, Milstein DM, et al. Why Rudolph's nose is red: observational study. BMJ 2012; 345: e8311.

2 Ball NJ, Kho GT, Martinka M. The histologic spectrum of cutaneous sarcoidosis: a study of twenty-eight cases. J Cutan Pathol 2004; 31: 160-168.

3 Spiteri MA, Matthey F, Gordon T, et al. Lupus pernio: a clinico-radiological study of thirty-five cases. Br J Dermatol 1985; 112: 315-322.

4 Haimovic A, Sanchez M, Judson MA, Prystowsky S. Sarcoidosis: a comprehensive review and update for the dermatologist: part I. Cutaneous disease. J Am Acad Dermatol 2012; 66: 699.el-699.el8.

5 Wei CH, Huang YH, Shih YC, et al. Sarcoidosis with cutaneous granulomatous vasculitis. Australas J Dermatol 2010; 51: 198-201.

\begin{tabular}{|c|c|}
\hline \multicolumn{2}{|c|}{ Differential diagnoses for Patient R } \\
\hline Aetiology & Diagnoses \\
\hline Inflammatory & Rosacea (rhinophyma) \\
\hline \multicolumn{2}{|l|}{ Infiltrates } \\
\hline \multicolumn{2}{|l|}{ Cellular } \\
\hline Lymphocytic & Tumid lupus, pseudolymphoma, Jessner lymphocytic infiltration \\
\hline Neutrophilic & Sweet syndrome \\
\hline Eosinophilic & Angiolymphoid hyperplasia with eosinophilia \\
\hline Granulomatous & Xanthogranuloma \\
\hline Mixed & Granuloma faciale \\
\hline \multicolumn{2}{|l|}{ Acellular } \\
\hline Mucin & Cutaneous mucinosis \\
\hline Amyloid & Cutaneous amyloidosis \\
\hline Tumours & $\begin{array}{l}\text { Basal cell carcinoma, amelanotic melanoma, cutaneous lymphoma, } \\
\text { Merkel cell carcinoma, angiosarcoma }\end{array}$ \\
\hline Infection & $\begin{array}{l}\text { Syphilis (Treponema pallidum), lupus vulgaris (Mycobacterium } \\
\text { tuberculosis), leishmaniasis (Leishmania spp) }\end{array}$ \\
\hline $\begin{array}{l}\text { Vascular } \\
\text { malformations }\end{array}$ & $\begin{array}{l}\text { Non-involuting congenital haemangioma, arteriovenous malformation } \\
\text { (especially Wyburn-Mason syndrome) }\end{array}$ \\
\hline
\end{tabular}

